\title{
Implications for food production, land use and rural development of the European Union's Single Farm Payment: Indications from a survey of farmers' intentions in Germany, Portugal and the UK
}

\author{
R.B. Tranter ${ }^{\mathrm{a}, *}$, A. Swinbank ${ }^{\mathrm{a}}$, M.J. Wooldridge ${ }^{\mathrm{a}}$, L. Costa ${ }^{\mathrm{b}}$, \\ T. Knapp ${ }^{\text {c }}$, G.P.J. Little ${ }^{\mathrm{d}}$, M.L. Sottomayor ${ }^{b}$ \\ a Centre for Agricultural Strategy, School of Agriculture, Policy and Development, \\ The University of Reading, P.O. Box 237, Reading, RG6 6AR, UK \\ ${ }^{\mathrm{b}}$ Faculty of Economics and Management, The Portuguese Catholic University, Centre Regional do Porto, \\ Rua Diogo Botelho 1327, 4169-005 Porto, Portugal \\ ${ }^{\mathrm{c}}$ Institut für Agrarökonomie, Georg-August Universität Göttingen, \\ Platz der Göttinger Sieben 5, 37073 Göttingen, Germany \\ ${ }^{\mathrm{d}}$ Environment, Food and Rural Affairs Committee, House of Commons, 7 Millbank, London SWIP 3JA, UK
}

\begin{abstract}
The 2003 reform of the European Union's (EU) Common Agricultural Policy introduced a decoupled income support for farmers called the Single Farm Payment (SFP). Concerns were raised about possible future land use and production changes and their impact on rural communities. Here, such concerns are considered against the workings of the SFP in three EU Member States. Various quantitative studies that have determined the likely impact of the SFP within the EU and the study countries are reviewed. We present the results of a farm survey conducted in the study countries in which farmers' responses to a decoupling scenario similar to the SFP were sought. We found that little short-term change was proposed in the three, rather different, study countries with only $30 \%$ of the farmers stating that they would alter their mix of farm activities. Furthermore, less than $30 \%$ of all respondents in each country would idle any land under decoupling. Of those who would adopt a new activity, the most popular choices were forestry, woodland and non-food crops.
\end{abstract}

\footnotetext{
* Corresponding author. Tel.: +44 (0) 118378 8155; fax: +44 (0) 1189353423.

E-mail address: r.b.tranter@reading.ac.uk (R.B. Tranter).
} 
Keywords: CAP reform; Food production; Land use and rural development; Farmers' intentions; Germany, Portugal and the UK

\section{Introduction}

In July 2002, the EU's Commissioner for Agriculture and Rural Development, Franz Fischler, proposed a significant change to the Common Agricultural Policy (CAP) (Commission, 2002). ${ }^{1}$ Arable area payments, and headage payments for beef cattle, sheep and goats, which then accounted for $61 \%$ of CAP budget expenditure on price and income support (Commission, 2002), and compensation payments for milk producers already agreed in Agenda 2000, would be decoupled from production, thereby giving farmers greater freedom to farm. In introducing its formal proposals for reform in January 2003, the Commission said: 'By providing greater farming flexibility, decoupling will improve the income situation of many farmers in marginal areas' (Commission, 2003). Although details changed during negotiations in the Council of Ministers, this was the core of the package agreed by Council in Luxembourg in June 2003. The new Single Payment Scheme introduced 'an income support for farmers' (Council, 2003: Article 1), commonly known as the Single Farm Payment (SFP), which was extended in 2004 to embrace direct payments on cotton, tobacco, olive oil and hops, and that came into effect in 2005 in most Member States.

During debate in Council, and elsewhere, concern was expressed that if payments were to be decoupled then farmers would be free to abandon agricultural production, with potentially adverse environmental, land use and rural developmental consequences, and to switch production to, say, field vegetables, providing unwelcome subsidised competition for traditional producers not currently in receipt of the SFP.

The new support system challenges policy makers and analysts, because the unprecedented extent and nature of the change means that there is absolutely no prior EU experience from which the parameters usually deployed by economists in their models (price elasticities of supply, for example) can be reliably estimated. ${ }^{2}$ The models that have been run, to date, have necessarily relied on 'guesstimates' of relevant adjustment parameters (see, for instance, Anton et al., 2005 and Renwick et al., 2003). Nevertheless, a conclusion of the EU-funded EPSON project was that farm incomes in the EU-15 will be only marginally affected by the introduction of the SFP (Shucksmith et al., 2005).

One way to obtain insight into the likely response of farmers is to undertake a carefully constructed survey of their future intentions. By chance, a major survey of farmers in Germany, Portugal and the United Kingdom (UK) was undertaken in the autumn and winter of 2001/2002, asking farmers how they might respond to various decoupling scenarios. These survey results are summarised in Tranter et al. (2004). This paper extracts and utilizes data from that survey, presents further analyses of it and focuses on survey farmers'

\footnotetext{
${ }^{1}$ This was known as the Mid-term Review, following an agreement in the previous CAP reform (Agenda 2000) that certain provisions would be reviewed part-way through the Agenda 2000 planning horizon (2000-2006).

${ }^{2}$ However, a sweeping change was made to agricultural policy in New Zealand in the mid-1980s and Australia, in 2000, abolished support arrangements for fluid milk overnight (Harris and Rae, 2006; Johnson, 2000).
} 
responses to a decoupling scenario close to the SFP. Throughout, we concentrate on what the survey told us about likely effects on food production, land use and rural development.

This paper proceeds as follows. First, we identify concerns expressed about 'desertification', other land use changes and the impact on rural communities in the EU consequent upon decoupling. Second, we outline the SFP, addressing concerns identified in the previous section (touching on cross-compliance, modulation and the switch of funds to rural development, partial decoupling, etc.), and explain how the scheme is being applied in the three study countries (Germany, Portugal and the UK). Third, we review some quantitative studies that have attempted to determine the likely impact of the SFP for EU-15 and our three study countries. Then, we present the results from the 2001/2002 farm survey, noted above. Finally, we draw our conclusions.

\section{Food production, land use and rural development issues arising from decoupling}

Three stages in the evolution of CAP support can be identified. In the archetypal CAP, pre-1992, support was linked to production, often the production of a processed product, such as butter, a beef carcass, or white sugar, that could be sold into intervention. In the MacSharry reforms of 1992, partial decoupling of support for cereal and beef producers was introduced. Although price support (and intervention) was not eliminated, the level of market price support was substantially reduced, and - in compensation for the implied loss of revenue - farmers received area and headage payments on the eligible crops sown, and animals kept. Thus, weight of output was no longer a determinant of the amount of CAP support received by the farmer. The Fischler reforms of 2003/2004, culminating in the Mid-term Review, took this one step further. Indeed, the Commission (2002) talked of 'completing the shift from product to producer support with the introduction of a decoupled system of payments per farm' ${ }^{3}$ The idea was that all direct payments (not simply those associated with the MacSharry reforms of 1992), previously paid on an area or headage basis, would be converted into the SFP. This would be an annual payment based on the amount of land kept in good agricultural and environmental condition, regardless of the level of crops grown or animals kept. The actual scheme, outlined below, is not quite as simple as this!

In discussing decoupling with stakeholders, it was found that there were two major issues with important food production, land use and rural development implications that arose: 'will land fall idle?' and 'will many farmers leave agriculture?' For some, the issue underpinning these questions is whether rural de-population might occur but it is not intended to address that question in this paper. Nevertheless, these concerns informed the questionnaire survey design implemented by Tranter et al. (2004) in 2001/2002 and are discussed in more detail below.

Will land fall idle? When farmers receive payments irrespective of how they use their land, marginal land might drop out of production. Such land idling may be concentrated in some regions, with negative implications for the countryside (see, for instance, National Trust, 2005). Whilst the extent of voluntary set-aside in the 1990s had not become a major issue (HGCA, 2005), under a regime of more-fully decoupled payments, as the SFP, there

\footnotetext{
${ }^{3}$ Nevertheless, a bond scheme, as proposed by Tangermann (1991) for example, would result in even greater decoupling by eliminating all future links with farming activity, and farmland. The survey of Tranter et al. (2004) was also designed to elicit farmers' reaction to this further stage in decoupling.
} 
would be no upper limit to idling, and whole farms could potentially be closed down. There are various forms of extensive land use that might spread if land has no longer to be planted to the grandes cultures in order to receive payments. With decoupling of livestock payments, idling might also spread to areas of extensive goat, sheep and cattle operations, which were formerly carried out in order to receive livestock payments. To set against this, it could be argued that under the EU's Nitrates Directive, more land might be required for slurry-spreading in the spring as a cheaper alternative to other methods of disposal.

Jones (2005) discussed the issue of whether to produce or not and tended to agree with commentators such as Nix (2005) that more far reaching changes may be seen in 2006 and beyond. However, the Commission (2003) addressed this concern in its proposals of January 2003: 'In order to avoid land abandonment as a result of decoupling, ... farmers will have to meet stringent land management obligations as part of the new cross-compliance requirements'. Furthermore, 'Payments will only be made to farmers actively producing or maintaining land in good agronomic condition, maintaining the link to land'. In the end, this did not satisfy all Member States, and so an option was built-in allowing them to adopt partial decoupling.

A further problem is the risk that land might be diverted from arable crops at the intensive, rather than the extensive, margin, with farmers switching to other products. Indeed, Cunha (2004) argued that those in southern Europe producing permanent crops such as vines or fruit trees could be particularly disadvantaged by former arable crop farmers converting to these uses. Consequently, land 'under permanent crops, forests or used for nonagricultural activities' cannot be used to validate SFP claims; and SFP claims cannot be made on land used to grow fruit and vegetables, or potatoes other than for the manufacture of potato starch (Council, 2003). However, these restrictions are currently under review.

Will many farmers leave agriculture? Decoupling payments from land use will not, in most cases, reduce farm revenues, for it allows farmers to use their resources more economically and therefore leads, for a given level of payments, to higher farm incomes. From this perspective there will be not more, but instead less, pressure for farmers to leave the land. However, as land no longer has to be planted, and animals no longer have to be kept in order to receive payments, the amount of labour required may decline if land use and livestock production decrease as a result of decoupling.

The reduced throughput would, thus, impact on ancillary industries supplying the sector and transporting and processing its product, with ensuing job losses and possible rural de-population. Feed mills, slaughter houses and co-operatives supplying inputs/marketing outputs could be especially affected (Courtney et al., 2007). The on-going process of CAP reform will eliminate export subsidies in due course which will necessitate further reductions in market price support and lead to an additional drop in production levels.

At the same time, under the SFP, farmers may continue the recent trend to spend more of their time (and more of their residual income) away from their farm businesses, further impacting upon the social viability of rural communities and the financial health of the wider rural economy. However, in the UK, SFP is treated as revenue for income tax purposes only if the farm business satisfies the definition of farming for tax purposes (HM Revenue and Customs, 2005). Moreover, to maintain eligibility for the SFP, land has to be maintained in good agricultural and environmental condition, and the other cross-compliance conditions met, which will require some minimal level of labour input. 


\section{The single payment scheme}

In practice, the SFP is being implemented in quite different ways across the EU. The situation for Germany, Portugal and the UK is summarised in Table 1. Only in Wales and Scotland is the 'pure' SFP scheme being implemented.

The original idea was that a SFP entitlement would be established for each farm, based on that farm's receipt of direct payments in the base period 2000-2002. To determine the entitlement, the annual average payment would be divided by the average number of farmed hectares on which the claims were based. Thus, a farm might have a SFP entitlement on, say, 107 hectares, at a rate, say, of $€ 162$ per hectare, reflecting the fact that the farm's average receipt in the base period was $€ 17,334$ per annum over an average area of 107 hectares. For the farm to claim its full SFP in future years, it would have to farm (or maintain in good agricultural and environmental condition) 107 hectares. As noted above, certain land uses (forestry, permanent crops, and in most instances, fruit and vegetables) would render the land ineligible for the SFP. Furthermore, cross-compliance provisions apply across all the farmed area (not just the area on which a SFP is claimed). ${ }^{4}$

However, two main variants to this basic model are possible, as reflected in Table 1 . First, rather than adopt full decoupling, Member States can retain some element of coupling, in an attempt to maintain farm production. Thus, for example, $25 \%$ of the old arable area payment can remain coupled to production. France in particular has made use of this option. The coupling provisions for the old livestock payments are complex, with Austria, Belgium, Denmark, Greece, France, The Netherlands, Portugal and Sweden adopting these provisions in various ways.

Second, rather than adopting the historic mode of making payments to a farm on the basis of that farm's historic entitlement, Member States can pool the SFP monies that would otherwise be paid in a particular region, and make payments on all eligible land on a flat-rate basis. This is the model to which Germany and England (but not Scotland, Wales and Northern Ireland) are moving; but for the moment they each have hybrid schemes involving a combination of the historic and flat-rate regionalised modes of payment. These country differences may well impact upon farmers' actual response to the decoupling of support implicit in the SFP, but this detail was not known to the respondents when they completed the survey (outlined below) in 2001/2002.

In passing, it should be noted that there is an EU provision to modulate the SFP. The first $€ 5000$ is exempt, but above $€ 5000$ a levy of $5 \%$ will ultimately apply, with the monies diverted to the rural development budget. In the UK, national modulation currently applies as well. Furthermore, from 2007 on, if budget funds are inadequate to meet all expected CAP expenditure, a new Financial Discipline can be triggered to reduce SFPs; and at the December 2005 meeting of the European Council, a decision was reached in principle to allow Member States to modulate payments at a rate up to $20 \%$.

\footnotetext{
${ }^{4}$ The regulation specifies $18 \mathrm{EU}$ directives, relating to the environment, public animal or plant health, and animal welfare, that must be respected; and authorises Member States to determine 'minimum requirements for good agricultural and environmental condition ..., taking into account the specific characteristics of the area concerned ...' (Council, 2003, Articles 3-9, and Annexes III and IV).
} 
Table 1

Implementation of the SFP in Germany, Portugal and the UK

\begin{tabular}{|c|c|c|}
\hline Country & Full or partial decoupling? & $\begin{array}{l}\text { Historic or regional (flat-rate) } \\
\text { implementation? }\end{array}$ \\
\hline Germany & $\begin{array}{l}\text { Full decoupling, except for hops, tobacco } \\
\text { (until 2009) and potato starch }\end{array}$ & $\begin{array}{l}\text { - A flat-rate per hectare arable payment in } \\
\text { each Länder } \\
\text { - A dynamic hybrid for livestock payments, } \\
\text { comprising a flat-rate grassland payment } \\
\text { and an historic element, switching } \\
\text { (between } 2010 \text { and 2013) into a fully } \\
\text { regionalised aid system }\end{array}$ \\
\hline $\begin{array}{l}\text { Portugal } \\
\quad \text { (excluding the } \\
\text { Azores and } \\
\text { Madeira) }\end{array}$ & $\begin{array}{l}\text { Full decoupling for arable crops but not } \\
\text { seeds; partial decoupling for some livestock } \\
\text { premiums (e.g. for some bovine animals and } \\
\text { sheep and goats) and olive oil and tobacco }\end{array}$ & Historic \\
\hline $\begin{array}{l}\text { United Kingdom } \\
\text { - England }\end{array}$ & Full decoupling in all of the UK & $\begin{array}{l}\text { - A dynamic hybrid moving to flat-rate } \\
\text { payments and fully regionalised by } 2012\end{array}$ \\
\hline - Wales & & - Historic \\
\hline - Scotland & & - Historic \\
\hline$-\mathrm{N}$. Ireland & & - Static vertical hybrid \\
\hline
\end{tabular}

Source: Agra Europe (2004); Horseman (2005); and European Commission (2007).

\section{Estimates of the likely impact on land use and food production of decoupling}

The impact of the Fischler reforms on land use and agricultural production could be far reaching. Thus, it is not surprising that considerable effort has been expended on attempting to measure the effects. Indeed, Gohin (2006) reviews and assesses seven recent exercises. Brief details of some estimates for the EU-15, Germany, Portugal and the UK, of possible impacts are shown in Table 2. It is interesting that, although most published literature on the results from various economic forecasting models agrees in general about the likely direction of the impact of the reforms, there is less consensus on the level of the impacts in some sectors. This, in part, reflects model structure, but it is largely dictated by the supply response rate assumed by the modeller and, as Gohin (2006) points out, on how accurately the baseline position is modelled. On the whole, modellers have tended to assume that cereal and oilseed production was less 'tied' to the old arable area payments scheme (because farmers had the option to set-aside additional arable land) than was beef and sheep production, where livestock numbers had to be maintained to collect the headage payment in full.

The lack of consensus is, perhaps, most evident in the beef sector where the estimated number of animals in national or in the aggregate EU herd, is consistently less than present herd sizes. The range of estimates in respect of the reduction in numbers in the EU suckler herd is from as little as 3.2\% (OECD, 2004) to 13.7\% (European Commission, 2003). The Irish Agriculture and Food Authority (Teagasc, 2003) formulating estimates of numbers based on earlier data (the July 2002 proposals) and, therefore, perhaps not strictly comparable, postulated an even greater reduction in numbers of beef animals in the EU herd of $18 \%$. In national terms, the scale of reduction in beef animal numbers ranges from $16.7 \%$ in the UK (Moss et al., 2005) to $29 \%$ in Germany (Offermann et al., 2004 ) and to as much as $36 \%$ in Portugal (Soares et al., 2004). 
Table 2

Estimates of the impact of the 2003 CAP reforms on land use and agricultural production (\% change on baseline)

\begin{tabular}{|c|c|c|c|c|c|c|c|c|c|}
\hline $\begin{array}{l}\text { Geographical } \\
\text { region }\end{array}$ & Date & $\begin{array}{l}\text { Soft } \\
\text { wheat } \\
\text { area }\end{array}$ & $\begin{array}{l}\text { Barley } \\
\text { area }\end{array}$ & $\begin{array}{l}\text { Oilseeds } \\
\text { area }\end{array}$ & $\begin{array}{l}\text { Beef } \\
\text { (suckler) } \\
\text { cow nos. }\end{array}$ & $\begin{array}{l}\text { Beef } \\
\text { production }\end{array}$ & $\begin{array}{l}\text { Ewe } \\
\text { nos. }\end{array}$ & $\begin{array}{l}\text { Sheepmeat } \\
\text { production }\end{array}$ & $\begin{array}{l}\text { Source of } \\
\text { estimate }\end{array}$ \\
\hline EU-15 & 2008 & $-7.5^{\mathrm{a}, \mathrm{c}}$ & $-7.5^{\mathrm{a}, \mathrm{c}}$ & - & - & $-7.5^{\mathrm{c}}$ & - & $-7.5^{\mathrm{c}}$ & $\begin{array}{l}\text { DEFRA } \\
(2003)\end{array}$ \\
\hline EU-15 & $\begin{array}{l}2009- \\
2010\end{array}$ & -2.6 & -0.9 & -2.9 & -13.7 & -2.7 & - & - & $\begin{array}{l}\text { European } \\
\text { Commission } \\
\text { (2003) }\end{array}$ \\
\hline EU-15 & $\begin{array}{l}2007- \\
2012\end{array}$ & -0.5 & -0.4 & -0.4 & -7.0 & -1.4 & -4.9 & -3.6 & $\begin{array}{l}\text { Binfield et al. } \\
\text { (2004) }\end{array}$ \\
\hline EU-15 & 2008 & -2.2 & $-2.5^{\mathrm{b}}$ & -2.8 & -3.2 & -0.6 & - & - & $\begin{array}{l}\text { OECD } \\
(2004)\end{array}$ \\
\hline EU-15 & 2010 & -2.0 & -1.0 & - & -18.0 & -6.0 & -7.0 & -8.0 & $\begin{array}{l}\text { Teagasc } \\
(2003)\end{array}$ \\
\hline Germany & 2012 & $-9.0^{\mathrm{a}, \mathrm{c}}$ & $-9.0^{\mathrm{a}, \mathrm{c}}$ & $-7.0^{\mathrm{c}, \mathrm{d}}$ & $-29.0^{\mathrm{c}}$ & -15.0 & - & - & $\begin{array}{l}\text { Offermann } \\
\text { et al. } \\
\text { (2004) }\end{array}$ \\
\hline Portugal & 2010 & -7.5 & -7.0 & -100.0 & -36.0 & -12.0 & -1.8 & +6.7 & $\begin{array}{l}\text { Soares et al. } \\
(2004)\end{array}$ \\
\hline UK & 2008 & $-17.5^{\mathrm{a}, \mathrm{c}}$ & $-17.5^{\mathrm{a}, \mathrm{c}}$ & - & - & $-10.0^{\mathrm{c}}$ & - & $-12.5^{\mathrm{c}}$ & $\begin{array}{l}\text { DEFRA } \\
(2003)\end{array}$ \\
\hline UK & 2014 & -0.6 & -0.3 & -1.0 & -16.7 & -7.8 & -6.8 & -9.5 & $\begin{array}{l}\text { Moss et al. } \\
(2005)\end{array}$ \\
\hline
\end{tabular}

Notes: -, not reported.

a All cereals.

${ }^{\mathrm{b}}$ For barley, maize and rye together.

${ }^{c}$ Average of reported range of values.

${ }^{\mathrm{d}}$ Oilseeds for human consumption only.

The range of estimates in respect of the consequent reduction in EU-15 production levels of beef is rather more conservative in nature. All projections are, however, for a reduction in aggregate production ranging from $0.6 \%$ (OECD, 2004) to $7.5 \%$ (DEFRA, 2003). In individual EU Member States, likely reductions in production are suggested at $15 \%$ in Germany (Offermann et al., 2004), 12\% in Portugal (Soares et al., 2004) and $10 \%$ in the UK by 2008 (DEFRA, 2003). A more recent UK estimate produced using the FAPRI GOLD model suggests a more modest reduction of $7.8 \%$ (Moss et al., 2005).

The arable sector estimates reveal a consistent decline for both cereals and oilseeds. It is noted, however, that the projected changes in Germany and Portugal at around $-9 \%$ (Germany, soft wheat and barley) and $-7.5 \%$ (soft wheat) to $-7.0 \%$ (barley), both Portugal, are higher than the EU across the board projections. DEFRA (2003) projections for the EU-15 for all cereals together are higher, at 7.5\%. Moreover, in the UK, for all cereals, DEFRA (2003) suggest that the change in production will be a reduction in the range of $-10 \%$ to $-25 \%$. The Moss et al. (2005) results, using the FAPRI GOLD model, are altogether more modest, for the UK at around $-0.6 \%$ for soft wheat, $-0.3 \%$ for barley and $-1.0 \%$ for oilseeds, although these data assume a comparator date of 2014 rather than 2008. 
As with cereals, it is also expected that a reduction in the area planted to oilseeds will be observed. Within the EU-15, the range of hectares planted extends from $-0.4 \%$ (Binfield et al., 2004) to $-2.9 \%$ (European Commission, 2003). In the UK, Moss et al. (2005) anticipate a change of $-1.0 \%$ while in Germany the change is expected to be rather larger at about $-7.0 \%$. The Portuguese study, however, clearly states that, without production subsidy, it is expected that all oilseed crop production will end completely. Within Portugal, sunflower is considered to be very much a marginal crop and production in the past was largely a consequence of the presence of a production subsidy - in Portuguese it is known as Girassídio or Sunfloweridy. Without the subsidy, the crop shows negative returns and it is considered not worth the effort expended on its cultivation.

The sheep sector also shows projected declines in both numbers of ewes and, generally, meat production. In the UK, the projections suggest a decline in sheepmeat production of between $9.5 \%$ (Moss et al., 2005) and 12.5\%, possibly as much as $15.0 \%$ (DEFRA, 2003). Moss et al. (2005) also suggest that the decline in sheepmeat production will be greater than the decline in the number of ewes kept, which implies counterintuitively to the Portuguese estimates, that the slaughter-weight of individual animals is likely to decline.

\section{The postal survey of farmers}

A postal survey was carried out in each study country during the winter of 2001/ 2002; full details are provided by Tranter et al. (2004). In the UK, farm incomes were then recovering slightly from their low point in 2000 , but the sector had been very badly shaken by the outbreak of foot and mouth disease that had raged through 2001. Indeed, implementation of the survey was delayed because of the outbreak (and, earlier, because of the BSE crisis that had erupted in Germany in the autumn of 2000), and it was only embarked upon once the disease was contained. The postal survey, however, predated the launch of the Mid-term Review of the CAP in July 2002 (Commission, 2002).

The survey sample was around 4500 farmers in each study country. A four-page questionnaire ${ }^{5}$ was used which included a stepwise approach to defining the new policy scenario and examining likely individual reactions. The questionnaire design and the procedure employed were as identical as possible in each country. The response rate was $40.2 \%$ for the UK, $36.8 \%$ for Germany and $33.4 \%$ for Portugal meaning at least 1400 'clean' responses for each country. These rates are particularly high for voluntary postal surveys of farmers. In addition, a series of on-farm interviews with 50 respondents in each country was carried out to act as a form of verification of the reliability of the postal answers and to 'tease out' reasons behind their answers to the postal survey questionnaire.

When respondents' characteristics were compared with the known overall national pattern of farm types, sizes and region, to check for sample bias before analysing the replies, it was found that the survey response might under-represent smaller farm businesses in both the UK and Portugal. However, an investigation into non-response bias, by testing the

\footnotetext{
${ }^{5}$ A copy of the questionnaire in English is available from the first-named author.
} 
first third of responses received against the last third, found very few statistically significant $^{6}$ different features showing that this type of bias was not prevalent.

Tranter et al. (2004) reviewed examples of intentions surveys in agriculture worldwide and discussed problems in designing and carrying out such surveys and interpreting the evidence they provide. A crucial question not often asked is whether such surveys provide answers that actually mirror how farmers will really behave in the future. However, Thomson and Tansey (1982), Gasson et al. (1998) and Harvey (2000) did just this for the UK and found that most farmers actually did what they said they would, especially for relatively short-term decisions or actions. So, Tranter et al. (2004) concluded that, for a situation such as the introduction of a decoupled support system akin to the SFP, provided the questionnaire was designed properly, the sample was large and included a full range of farm types and sizes the results are liable to be reasonably accurate. But, it should be recognised that there might be a difference between asking farmers about how they might react to a hypothetical changed policy scenario and an actual change in policy. For example, would surveyed farmers have given the same set of answers following the publication of the Commission's plans in 2002?

The questionnaire began by asking for contextual details of the farm business, and demographic and attitudinal characteristics of the respondents. It then sketched a support scenario:

Please imagine that crop payments will be detached from current land use. Thus, future payments will no longer depend on which crop you plant, the area planted or even whether land is planted at all. Instead, payments will be made at a flat-rate, on the basis of your average arable area claims during the previous three years. Our proposal will also affect the livestock sector similarly, with future payments being based on the average number of livestock units (cattle and sheep) for which the farm claimed payments in the previous three years.

This scenario corresponds, approximately, to the SFP subsequently adopted in the Fischler reforms although, as shown in Table 1, the method of implementation varies. Table 3 details the overall response by study country to four key questions relevant to the theme of this paper - would they alter their mix of farm activities; would they leave any of their land idle; would their intensity of production change; and would the amount of labour employed on their farm change. It shows, for example, that around $67-69 \%$ of the respondents said they would not alter their mix of farm activities if the proposed policy change were introduced. It is probably wise to interpret the responses as indications of the respondents'

\footnotetext{
${ }^{6}$ In order to test whether differences in replies to questions between the various sub-groups were likely to have occurred by chance or otherwise, the responses were tested for statistical significance. The replies were in three distinct forms. First, some replies, or variables, were in a continuous form, such as size of farm or age of farmer. These needed their differences in mean values to be compared using the Student $t$-test. Second, some replies were in the form of ordinal scales where, for example, agreement levels with statements were given scores. These were compared using the Mann-Whitney $U$-test. Third, some responses were in a 'discrete' or categorical form (i.e. they had a livestock farm or a crop farm). Here, differences in the proportional distribution of replies between such sub-groups were compared using the $\chi^{2}$-test. If there was no greater chance than $5 \%$ that such a large value of $t$ or Chi-square or $U$ statistic could have occurred by chance, the difference was stated to be statistically significant. The level of significance is shown as follows: where there is less than $5 \%$ probability that the observed difference would have occurred by chance the mark * will be recorded; where the probability is less than $1 \%$ the mark $* *$ will be recorded; and $* * *$ where the probability is less than $0.1 \%$.
} 
Table 3

Response of survey respondents to four key questions about their behaviour under decoupling

\begin{tabular}{|c|c|c|c|}
\hline & \multicolumn{3}{|c|}{$\begin{array}{l}\text { Proportion of respondents }(\% \\
\text { in }\end{array}$} \\
\hline & UK & Germany & Portugal \\
\hline \multicolumn{4}{|l|}{ Who responded } \\
\hline No to the question: 'Would you alter your mix of farm activities?' (1) & 69.1 & 66.8 & 67.1 \\
\hline None to the question: 'Would you leave any of your land idle?' (2) & 79.9 & 59.7 & 52.2 \\
\hline $\begin{array}{l}\text { Remain unchanged to the question: 'Would your intensity of production } \\
\text { change?' (3) }\end{array}$ & 59.3 & 60.3 & 52.6 \\
\hline $\begin{array}{l}\text { Remain unchanged to the question: 'Would the amount of labour employed } \\
\text { on your farm change?' (4) }\end{array}$ & 72.7 & 55.6 & 55.1 \\
\hline $\begin{array}{l}\text { No to (1) above, none to (2) above and remain unchanged to (3) and (4) } \\
\text { above }\end{array}$ & 32.6 & 22.4 & 18.4 \\
\hline
\end{tabular}

short-term intentions. It is interesting to see how close this proportion was for each of the three countries. The preponderant response to all four individual questions across the three survey countries was 'no change', with UK farmers indicating the least, and Portuguese farmers the most, intent to change.

There were some interesting differences. For example, in the UK, $73 \%$ of farmers with less than 100 ha farms said they would not alter their mix of farm activities, as opposed to $65 \%$ of farmers with 100 ha or more $(* * *)$. Similarly, the older the respondent (51 and over, ***), and the earlier they left full-time education (up to and including $19, *$ ), the more likely they were to say they would not alter their mix of activities.

Table 3 also shows (row five) the proportion of the respondents who said they would not alter their mix of farm activities or leave any of their land idle or change their intensity of production or their level of labour employed under the decoupling scenario. In effect, $32.6 \%$ of respondents in the UK, $22.4 \%$ in Germany and $18.4 \%$ in Portugal said: 'we would carry on as before making no changes at all to our farming systems'. These 'no change' respondents were not only numerous, they also formed much of the total area farmed by all respondents in each country: $25.6 \%$ in the UK, $12.4 \%$ in Germany and $29.1 \%$ in Portugal.

The above figures suggest there might be differences in farm size between farmers who said they would or would not change their systems under decoupling. Thus, this was investigated and it was found that in the UK and Germany those suggesting 'no change' had smaller farms on average than those who indicated that they would change whereas, in Portugal, the opposite trend was visible probably because of marked regional differences in size. However, only in the UK were these observed differences statistically significant (at the $* *$ level).

Some would say those advocating 'no change' might be older than those planning change as they might be more set in their ways and be more ready to sit back and see what happens. Thus, the existence of such a difference was examined. Whilst in Germany no significant differences were found, these were significant in Portugal where the 'no change' group were younger (at the $* * *$ level) and in the UK where they were older (at the $* * *$ level). Why this was so is not clear but, for Portugal, it could be that the younger farmers are those who have relatively recently entered farming through the intensive fruit and vegetable route or who are tied-in to a grant-aided project, with restrictions on crop mix or 
production structures changes. In addition, Alves et al. (2003) point out that older farmers in Portugal are concentrated in the extensive farming areas of the mountainous north.

Those who said they would alter their activity mix (some $32 \%$ of all respondents across all three countries), as a result of the introduction of decoupling, were then asked about the nature of their likely change. This was not only to obtain an assessment of the land use impact the suggested policy change would have on existing farm enterprises, but also to gauge the potential extent of farmers switching between enterprises, with decoupling now freeing them to move between sectors without fear of losing their direct payments.

Table 4 shows the nature of the respondents' proposed change in their main activity. It includes all respondents together, classified by main farm activity, including those who had answered they would not alter their mix of activities at all. The overall picture of a reduction in enterprises involving sheep and beef cattle, as a main activity, is most likely due to the breaking of the link between the amount of headage payments and livestock numbers. The predicted increases in dairying, and the results for cereals, probably reflect these farmers' belief that it will be necessary to expand the scale of their main activities in order to spread costs and become more competitive under any policy reform scenario. The general tendency for increases in other activities, such as permanent crops, pigs and poultry, horticulture and other vegetable and root crops under the category of general cropping, suggests that farmers perceived the possibility of an upturn in the relative profitability of these, less supported, sectors under the proposed policy change. However, it should be remembered that, under the actual Single Payment Scheme, farmers will not be able to switch to permanent crops and into horticulture without forfeiting their right to claim SFP on that land. The right-hand column reminds us that, as shown in Table 3, most respondents indicated that the suggested policy reform was unlikely to prompt them to make any immediate changes to their current mix of land use. This finding could well provide comfort to policy makers although it is interesting that pigs and poultry farmers, and those in horticulture, were the least likely to suggest they would not change at all.

The numbers across the columns of Table 4 do not sum to 100 because the changes shown in the first two columns are only for the main activity on the farm; the remainder represents predicted changes to secondary activities. As a result, it is the analysis of changes to these secondary activities, as well as the adoption of new activities which give the best guide to the amount of switching between enterprises that would result from the suggested policy change. The fact that over twice the number of cereal farmers said they

Table 4

Changes in main enterprise for respondents under decoupling by farm type, UK, Germany and Portugal together

\begin{tabular}{lccc}
\hline Main activity & \multicolumn{2}{l}{ Nature of change in activity $(\%$ of total) } \\
\cline { 2 - 4 } & Increase & Decrease & No change \\
\hline Dairying & 19.3 & 5.2 & 68.1 \\
Extensive sheep/cattle & 6.8 & 14.0 & 69.8 \\
Intensive sheep/cattle & 6.9 & 9.9 & 70.7 \\
Cereals & 10.2 & 10.0 & 64.4 \\
General cropping & 9.9 & 3.2 & 65.4 \\
Permanent crops & 10.4 & 3.8 & 67.9 \\
Pigs/poultry & 10.9 & 3.6 & 59.9 \\
Horticulture & 12.2 & 4.1 & 62.2 \\
\hline
\end{tabular}


Table 5

Respondents indicating they would adopt a new activity under decoupling, the UK, Germany and Portugal together

\begin{tabular}{lc}
\hline Activity to be adopted & Proportion of respondents $(\%)$ \\
\hline Dairying & 7.1 \\
Extensive sheep/cattle & 9.0 \\
Intensive sheep/cattle & 9.5 \\
Cereals & 7.0 \\
General cropping & 8.2 \\
Permanent crops & 7.5 \\
Pigs/poultry & 7.5 \\
Horticulture & 9.2 \\
Forestry/woodland & 14.1 \\
Non-food crops & 12.8 \\
Other activities & 8.1 \\
\hline
\end{tabular}

would increase, rather than decrease, activities such as permanent crops, horticulture and general cropping, might be thought to support fears that decoupling would have a destabilising effect on fruit and vegetable markets. However, the numbers of respondents predicting this change were relatively small, representing only around $7 \%$ of all the mainly cereal farmers in our sample.

Table 5 shows the proportion of respondents predicting the adoption of one or more new activities. It seems from these results that the proposed new adoption of activities in numbers is pretty evenly spread, apart from more for non-food crops and forestry and woodland. Again we should caution that under the SFP scheme actually adopted, a switch to horticulture, permanent crops or forestry might not be attractive. The outcome is slightly biased by the Portuguese results, as considerably more of their farmers anticipate a move into an alternative activity. There, as in the UK, but to a lesser extent, forestry was the most popular new choice.

As mentioned above, a fear associated with decoupling is the expectation that large areas would be left idle with the associated problems of landscape damage, unemployment, fire risk from an increase in scrub and the possible loss of biodiversity. Table 6 shows, as summarised in Table 3, that not only would at least $52 \%$ of farmers in each of the three countries leave no land idle at all (in the UK this figure is around $80 \%$ ), but considerable numbers also would idle less than half their land. Within these overall figures, there were interesting statistically significant differences by farm and farmer type. For example, in the UK, relatively more of the respondents with 100 ha or over would idle

Table 6

Respondents' answers to the question of whether they would leave any of their land idle under decoupling

\begin{tabular}{lccc}
\hline \multirow{2}{*}{ Action } & \multicolumn{2}{l}{ Proportion of respondents $(\%)$} & Portugal \\
\cline { 2 - 4 } & UK & Germany & 52.2 \\
\hline None & 79.9 & 59.7 & 24.4 \\
Less than half & 15.4 & 28.7 & 5.6 \\
Around half & 3.1 & 4.7 & 8.5 \\
More than half & 0.7 & 2.5 & 9.3 \\
All & 1.0 & 4.4 & \\
\hline
\end{tabular}


land than those with less $(* * *)$ whereas, in Portugal, relatively more of those with less than 50 ha farms would idle land than those with larger farms $(*)$. In the UK, farmers who had $50 \%$ or more of their income from non-farm sources were more likely to leave some land idle than those who obtained the majority of their income from the farm $(* * *)$. In Portugal, considerably fewer of the respondents who said a successor was definitely or very likely to have been identified would leave land idle, compared to those who had not identified one $(* * *)$.

\section{Conclusions}

The results from the postal survey of farmers in the UK, Germany and Portugal, suggest that any stakeholder misgivings about decoupling support for farmers were misfounded in terms of food production, land use and rural development issues. They suggest that there would likely be relatively little short-term change from the status quo if the proposed changed decoupled policy scenario had been introduced. Furthermore, it has been shown that a striking feature of the survey results is how very similar the responses were, whether they were from the UK, Germany or Portugal, three countries with widely different rural and farming situations both culturally, geographically and politically.

It is interesting to compare the survey results for a decoupled scenario without crosscompliance measures, with the results of some forecasts for the three study countries, after the introduction of the SFP (with cross-compliance) presented in Table 2. There, it can be seen that beef production in Germany, Portugal and the UK was forecast to fall by $15.0 \%$, $12.0 \%$ and $10.0 \%$, respectively; in our survey (Table 4), for main enterprises in the three countries together, $14.0 \%$ would decrease their extensive sheep/cattle enterprises and $9.9 \%$ would decrease their intensive sheep/cattle enterprises. To set against this, around $7 \%$ said they would increase their main sheep/cattle enterprises whether extensive/intensive. Summarising, survey results, whilst suggesting there would be a fall in beef production, indicate that this would not be quite as large as that forecasted by the modelling studies.

Turning to the equivalent comparison for cereals area, Table 2 shows forecasts for Germany, Portugal and the UK of a fall of $9.0 \%, 7.5 \%$ and $17.5 \%$, respectively. However, the survey results for cereals in Table 4 show that whilst $10.0 \%$ of the respondents would decrease their cereals, $10.2 \%$ would increase this activity indicating that, in our survey, perhaps a more positive attitude towards cereal production in a decoupled world was shown than the econometric forecasts reviewed here.

Around $30 \%$ of the respondents in each study country said they would alter their mix of farm activities when support payments were decoupled from current land use and production. With the exception of forestry and woodland, the spread of potential new enterprises the farmers said they would undertake on the introduction of the proposed decoupled support scheme was very similar; this finding was markedly skewed by results from Portugal, where not only did proportionately more of their farmers opt for taking up a new activity, but forestry and woodland was the most popular choice. Given the options actually available under the Single Payment Scheme regarding the eligibility of land for SFPs, the responses might have differed.

There was, though, one issue of marked difference between the study countries highlighted above - that of the likelihood of land abandonment once decoupling took place. Whilst at least $50 \%$ in each country said they would leave no land idle, and considerable 
numbers would idle less than half their land, in Portugal nearly $20 \%$ would idle all or more than half their land, a much larger proportion than in Germany and, in turn, this was much more than in the UK. In Portugal there was some evidence that the total area idled would be largely due to small extensive farms being abandoned in the northern mountain areas (Alves et al., 2003). Again, it may well be that the actual provisions in the Single Payment Scheme, particularly on cross-compliance, will lead farmers to abandon less of their land.

All in all then, the responses of farmers to the proposed decoupling of support, whilst at times somewhat difficult to interpret, have provided valuable evidence to suggest that there would be relatively few practical management problems in the short-term at the farm level as the SFP is introduced.

It will, of course, be some years before farmers adjust to the new support arrangements: it takes time to assess the changes, and their implications for the farm business; and it would be understandable if many farmers initially adopted a 'wait and see' stance, worried that if they did make early changes without fully understanding the ramifications, they might prejudice their eligibility for the SFP. However, whilst only a theoretical possibility at the time of our survey in 2001/2002, decoupling (in the form of the SFP) has now happened. Thus, revisiting the German, Portuguese and British farmers who responded to the survey, in 2008 or thereabouts, to see how they have acted, could be a useful check of the predictive ability of farmer intentions surveys of the sort reported here. It would also be a good way to review the different behaviours consequent on a real policy outcome (the SFP) compared with the hypothetical one of a very similar nature examined here.

\section{Acknowledgements}

This paper uses data from a research project ('An assessment of the practicalities and acceptability of a bond scheme as part of CAP reform - QLRT-1999-01510') financed under the Fifth Framework Research Programme of the European Commission. The authors are most grateful to the Commission for financial support but the views expressed here are theirs alone and not those of the Commission.

\section{References}

Agra Europe, 2004. EP/7, 6 August.

Alves, A.L., Carvalho, N.S., Silveira, S.C., Marques, J.P., Horta, A.L., 2003. O abandono da activadade agrícola. Grupo de trabalho Agro-Ambiental junto do Secretário de Estado do Desenvolvimento Rural. Ministério da Agricultura do Desenvolvimento Rural e das Pescas e Ministério do Ambiente, Lisboa.

Anton, J., Cahill, C., 2005. Towards evaluating 'more decoupled' payments: an empirical approach. Paper presented at the International Agricultural Trade Research Consortium Summer Symposium, Seville, 20-21 June 2005 .

Binfield, J., Donnellan, T., Hanrahan, K., Hart, C. Westhoff, P., 2004. CAP Reform and the WTO: Potential Impacts on EU Agriculture. Paper prepared for the American Agricultural Economics Association Annual Meeting, Denver, Colorado, USA

Commission of the European Communities, 2002. Communication From the Commission to the Council and the European Parliament. Mid-term Review of the Common Agricultural Policy. COM (2002) 394. CEC, Brussels.

Commission of the European Communities, 2003. Proposal for a Council Regulation Establishing Common Rules for Direct Support under the Common Agricultural Policy and Support Schemes for Producers of Certain Crops, .... COM (2003) 23. CEC, Brussels. 
Council of the European Union, 2003. Council Regulation (EC) No. 1782/2003 of 29 September 2003 establishing common rules for direct support schemes for farmers... Official Journal of the European Union L270, 1-69.

Courtney, P., Mayfield, L.E., Tranter, R.B., Jones, P.J., Errington, A.J., 2007. Small towns as 'sub-poles' in English rural development: investigating rural-urban linkages using sub-regional Social Accounting Matrices. Geoforum (forthcoming).

Cunha, A., 2004. A role for direct payments? The Doha Round, EU enlargement and prospects for CAP reform. In: Swinbank, A., Tranter, R. (Eds.), A Bond Scheme for Common Agricultural Policy Reform. CABI Publishing, Wallingford.

Department for Environment, Food and Rural Affairs, 2003. Assessment of the economic impact of the commission's long term perspective for sustainable agriculture. Agricultural Policy and Food Chain Economics Division, DEFRA, London.

European Commission, 2003. Reform of the Common Agricultural Policy. A long-term perspective for sustainable agriculture. Impact Analysis. Directorate-General for Agriculture, European Commission, Brussels.

European Commission, 2007. Overview of the implementation of direct payments under the CAP in Member States. $<$ http://ec.europa.eu/agriculture/markets/sfp/ins_en.pdf $>$.

Gasson, R., Errington, A.J., Tranter, R.B., 1998. Carry on Farming. A Study of How English Farmers have Adapted to the Changing Pressures on Farming. Wye College Press, University of London.

Gohin, A., 2006. Assessing CAP reform: sensitivity of modelling decoupled policies. Journal of Agricultural Economics 57, 415-440.

Harris, D., Rae, A., 2006. Agricultural policy reform and industry adjustment in Australia and New Zealand. In: Blandford, D., Hill, B. (Eds.), Policy Reform and Adjustment in the Agricultural Sectors of Developed Countries. CABI Publishing., Wallingford.

Harvey, D.R., 2000. Farmers' Intentions Survey, 1994-1997: Final Report. Special Studies in Agricultural Economics: No. 47. Department of Agricultural Economics and Food Marketing, The University of Newcastle upon Tyne, Newcastle upon Tyne, UK.

HM Revenue and Customs, 2005. Tax Bulletin Special Edition - June 2005. <http://www.hmrc.gov.uk/bulletins/ tb-se-june2005>.

Home Grown Cereals Authority, 2005. Planting Survey June 2005. http://www.hgca.com.

Horseman, C., 2005. CAP reform implementation: a country-by-country guide. Paper presented at an Agra Informa/Agra Europe Practical Seminar on Agricultural Policy in Europe, 6-7 July, London.

Johnson, R.W.M., 2000. Reforming EU Farm Policy: Lessons from New Zealand. Occasional Paper 112. The Institute of Economic Affairs, London.

Jones, J., 2005. To produce or not to produce? - Is that the question? Journal of Farm Management 12, 235-249.

Moss, J., Binfield, J., Westhoff, P., Kostov, P., Patton, M., Zhang, L., 2005. Analysis of The Impact of the Fischler Reforms and Potential Trade Liberalisation. Food And Agricultural Policy Research Institute (FAPRI).

National Trust, 2005. Impact of CAP Reform on the English Uplands. A National Trust Discussion Paper. National Trust, Swindon.

Nix, J., 2005. Farm Management Pocketbook, 36th ed. The Andersons Centre, Melton Mowbray.

Offermann, F., Kleinhanss, W., Huettel, S., Kuepker, B., 2004. Assessing the 2003 CAP Reform Impacts on German Agriculture using the Farm Group Model FARMIS. Institute of Farm Economics, Federal Agricultural Research Centre, Braunschweig.

Organisation for Economic Co-operation and Development, 2004. Analysis of the 2003 CAP Reform. OECD, Paris.

Renwick, A., Revell, B., Hodge, I., 2003. Preliminary analysis of partial decoupling. Final report for the Department of Environment, Food and Rural Affairs. Paper prepared for DEFRA by Harper Adams University College and the University of Cambridge. <http://statistics.defra.gov.uk/esg/reports/ partdeco.pdf $>$.

Shucksmith, M., Thomson, K., Roberts, D., 2005. The CAP and the Regions: Territorial Impact of Common Agricultural Policy. CABI Publishing., Wallingford.

Soares, F.B., Coelho, C., 2004. Analysis of the impact of the Luxembourg agreement on reform of the common agricultural policy on the agri-food sector of Portugal: an application of the AG-MEMOD model. Paper prepared for the Fourth Congresso Nacional dos Economistas Agrícolas. Faro, Portugal. 
Tangermann, S., 1991. A Bond Scheme for Supporting Farm Incomes. In: Marsh, J.S., Green, B., Kearney, B., Mahé, L., Tangermann, S., Tarditi, S. (Eds). The Changing Role of the Common Agricultural Policy: The Future of Farming in Europe. London, Belhaven.

Teagasc, 2003. An analysis of the effects of decoupling direct payments from production in the beef, sheep and cereal Sectors. Report prepared for the Department of Agriculture and Food by the Rural Economy Research Centre. Teagasc, Dublin.

Thomson, K.J., Tansey, A.W., 1982. Intentions surveys in farming. Journal of Agricultural Economics 33, 83-88. Tranter, R., Costa, L., Knapp, T., Little, J., Sottomayor, M., 2004. Asking farmers about their response to the proposed bond scheme. In: Swinbank, A., Tranter, R. (Eds.), A Bond Scheme for Common Agricultural Policy Reform. CABI Publishing., Wallingford. 